\title{
Effect of nucleation mechanism on the structure of polyfunctional calcium phosphate glass materials
}

\author{
O.V.Savvova, O.V.Babich, G.N.Shadrina \\ Chair of Technology of Ceramics, Refractories, Glass and Enamels, \\ National Technical University "Kharkiv Polytechnic Institute", \\ 21 Frunze Str., 61002 Kharkiv, Ukraine
}

Received July 7, 2014

\begin{abstract}
Effect of the nucleation mechanism on structure of polyfunctional calcium silicophosphate glass materials has been studied. It has been established that the structure differentiation via liquation mechanism with formation of the nanoscale spherical nonuniformities within microbeads and consequent structure arrangement prove the ides studied materials with glass-crystalline structure during thermal treatment. Provision of fine volume crystallization of carbon-hydroxyapatite in the structure of materials with the crystal size of about $1 \mu \mathrm{m}$ allows obtaining bioactive glass materials and coatings for bone implants with mechanical properties that allow their application on loaded areas of a bone.
\end{abstract}

\begin{abstract}
Исследовано влияние механизма нуклеации на структуру полифункциональных кальцийсиликофосфатных стекломатериалов. Установлено, что дифференциация структуры по ликвационному механизму с образованием наноразмерных сферических неоднородностей внутри микрокапель с последующим упорядочением их структуры обеспечивает ситаллизированную структуру в процессе термообработки исследуемых стекломатериалов. Обеспечение объемной тонкодисперсной кристаллизации карбонатгидроксиапатита в структуре материалов с размером кристаллов около 1 мкм позволяет получить биоактивные стекломатериалы и покрытия для костного эндопротезирования с прочностными свойствами, обеспечивающими их использование на нагружаемых участках кости.
\end{abstract}

Вплив механізму нуклеації на структуру поліфункціональних кальційсилікофосфатних скломатеріалів. О.В.Саввова, О.В.Бабіч, Г.М.Шадріна .

Досліджено вплив механізму нуклеації на структуру поліфункціональних кальційсилікофосфатних скломатеріалів. Встановлено, що диференціація структури за лікваційним механізмом з утворенням нанорозмірних сферичних неоднорідностей в середині мікрокапель з наступним упорядкуванням їх структури забезпечить ситалізовану структуру у процесі термообробки дослідних скломатеріалів. Забезпечення об'ємної тонкодисперсної кристалізації карбонатгідроксиапатиту у структурі матеріалів з розміром кристалів $\approx 1$ мкм дозволяе отримати біоактивні скломатеріали та покриття для кісткового ендопротезування 3 міцносними властивостями, які забезпечують їх використання на навантажених ділянках кістки.

\section{Introduction}

There is a steady trend in global practice toward creation of the new functional implant materials with preset properties, which conform by chemical composition and differentiated structure of their surface layers to the nature and sequence of biochemical reactions on the contact with living bone tissue [1]. Stimulation of the bone tissue regeneration processes is possible via active 
exposure on the bone cells of living organism and implant material, especially in the presence of nanostructures of chemical compounds in it. Effective control of properties of these materials may be achieved in thermodynamically non-equilibrium conditions only in obtaining the highly ordered self-organizing dissipative structures that have certain shape and characteristic time-space parameters [2].

In creation of the new generation of functional bioactive nanomaterial, which widely used as bone implants in orthopedics and dentistry [3], biological filters [4] and biocide coatings on metals [5], a special place is taken by glass-ceramic materials due to their highly ordered structure selforganization, both on stage of nucleation and during their following evolution [6].

Obtaining of those materials with the high level of technological and performance properties is closely related with provision of their structure nonuniformity by directed crystallization. During formation of the glass-ceramic materials and their microheterogeneity, an important role belongs to affinity of original glasses to liquation. According to B.G.Varshal [7], metastable liquation promotes the fast crystals formation by facilitation of diffusion processes and, as a consequence, by approaching of the glass compositions to the composition of the future crystals. The liquation leads to development of inner phase boundaries, where, in transition layer with intermediate structure, potential barrier of the nuclei formation is decreased [8].

Features of the structure formation in phosphate glasses have been considered in detail by A.N.Lazarev [9] and representative of Riga material science school [10]. P.D.Sarkisov with coworkers [3] in their research of the structure of bioactive calcium phosphate glasses devote special attention to determining the effect of phase separation processes in the glasses on their crystallization ability and resorption ability. The main factor in synthesis of apatitecontainig glass-ceramic materials is provision of volume uniform fine crystallization of calcium phosphates, particularly via nucleation by the liquation mechanism. However, there exists a complexity of structure identification on initial stages of the nucleation. This is explained by similarity of the fluctuation and liquation structures, because the latter is developed from the fluctuation structure and due to fluctuation. That is why for development of the fine volume crystallized glass-ceramic materials and coatings for bone implants, especially with reduced resorption times, it is crucial to research the nucleation mechanism in calcium phosphate glasses under thermal treatment conditions.

\section{Experimental}

In our previous work we selected the following systems as bases for glass-ceramic materials and bioactive glass-ceramic coatings on titanium: (I) $\mathrm{Na}_{2} \mathrm{O}-\mathrm{K}_{2} \mathrm{O}-\mathrm{CaO}-\mathrm{MgO}-$ $\mathrm{SrO}-\mathrm{TiO}_{2}-\mathrm{ZrO}_{2}-\mathrm{Al}_{2} \mathrm{O}-\mathrm{B}_{2} \mathrm{O}_{3}-\mathrm{P}_{2} \mathrm{O}_{5}-\mathrm{SiO}_{2}$ and (II) $\mathrm{Na}_{2} \mathrm{O}-\mathrm{CaO}-\mathrm{ZnO}-\mathrm{TiO}_{2}-\mathrm{ZrO}_{2}-\mathrm{Al}_{2} \mathrm{O}-\mathrm{B}_{2} \mathrm{O}_{3}-$ $\mathrm{P}_{2} \mathrm{O}_{5}-\mathrm{SiO}_{2}$. In the selected systems the areas of glass formation were established and glasses were synthesized, which were used as bases for obtaining the glass-ceramic material by ceramic technology. Their physico-chemical and technological properties were investigated [11, 12].

It was established that feature of the model glasses obtained on the base of system $I$ is formation of crystalline hydroxyapatite (HAP), while for the glasses of system II - formation of crystalline HAP and carbonate hydroxyapatite (CHAP) phase during cooling. It was found that invert calcium silicophosphate glass, T3 (system I) in presence of crystallization initiator $\mathrm{TiO}_{2}$, content of $\mathrm{R}_{2} \mathrm{O}=9$ mol. $\%$ and for $\mathrm{CaO} / \mathrm{P}_{2} \mathrm{O}_{5}$ ratio of 2 is characterized by presence of HAP in amount of 16 vol. \% after melting. For high silica glass ZF-1 (system II) increase of $\mathrm{CaO} / \mathrm{P}_{2} \mathrm{O}_{5}$ ratio to 4 , content of $\mathrm{R}_{2} \mathrm{O}$ to $15 \mathrm{~mol}$. \%, as well as presence of the crystallization initiator $\mathrm{ZnO}$ leads to increase of quantity of the crystalline phases of HAP and CHAP in it to 10 vol. \% after melting. Above-mentioned glasses may be used as a base for the functional bioactive glass-crystalline materials and coatings on titanium.

The aim of this work is investigation of effect of the nucleation mechanism in developed glasses on their structure.

Methods of investigation. Presence and identification of the crystalline phase were carried out by using X-ray diffraction analysis on DRON-3M diffractometer, and petrographic analysis on optical microscope MI-2e. Temperature of thermal treatment was established by differential thermal analysis on Paulic-Paulic-Erdey derivatograph and with gradient-thermal analysis. Microstructure of the glasses was investigated with EMV-100AK electron microscope. Viscosity of the glasses was determined by string elongation method on the 
viscosimeter developed in JSC Glass Institute (Russian Federation).

With the purpose of investigating the nucleation mechanism in calcium silicophosphate glasses, characteristic temperatures below, near and above softening temperature were chosen, at which thermal treatment of the glasses was carried out. The choice of these temperatures was made taking in account known ideas by V.N.Filipovich concerning sequence of the glass structure formation stages during directed crystallization [13].

On the first stage, being the nucleation process, conditions for fast formation of the crystals at temperatures of $t_{1}$ are created by development of metastable liquation process. This process leads to uniform and fast formation of dropwise areas with different composition in original glasses, sizes of which increase with time.

On the second stage during the glass thermal treatment at $t_{2}$ temperature, first appear such crystalline phases, which have the highest nucleation speed and are easily wetted by the glass, therefore they remain strongly bonded with it. This stage is basically formation of amorphous clusters around the nanocrystalline nuclei, which are then consolidated into residual mesophase with formation of macroscopic dissipative structure.

On the third stage, at $t_{3}$ temperature, the first main glass-ceramic phase begins to quickly form and slowly grow due to slow diffusion rate and structural transformations, as crystallization processes take place at relatively low temperatures and because of this are quite slow.

On the fourth stage at increased temperature, the rate of crystal growth increases and "final" crystallization takes place, which corresponds to the main exothermal peak on DTA curve [12].

In order to identify the structures of experimental glasses on initial stages of the nucleation, the glass areas without crystallization were selected [7].

\section{Results and discussion}

Electron-microscopic investigations allowed to conclude that initial T3 glass is a polyphase system consisting of mother glass matrix and insular dropwise formations having sizes of $\approx 0.01 \mu \mathrm{m}$. Apart from sharpness of the shown microstructure, the fact of regular position of spherical nonuniformities along the straight lines with for- mation of chains in some regions (Fig. 1a) is intriguing.

This microliquation structure with nonuniformities of about $100 \div 500 \AA$ is a pre-transitional fluctuation structure inherent for the glass as a single, yet micrononuniform phase. This conforms to the requirements of minimal change of thermopotential of fluctuation areas with the form that is close to spherical. In this respect, formation of oblong areas usually explained by their fusion. Single spherical nonuniformities, both convex and concave, with size of $0.5-1.0 \mu \mathrm{m}$ are also observed on the glass surface. At the thermal treatment of T3 glass (temperature $t_{1}=660^{\circ} \mathrm{C}$ ) the structure formed during its cooling changes its pattern (Fig. 1b).

In conditions of rather high concentration of the nonuniformities for this glass the phase distribution with formation of double network structure is observed when relative volume of each phase is close to 50 vol. \%. Such structure differentiation is inherent to liquation by spinodal mechanism and is manifested by fusion of spherical nonuniformities of about $100 \mathrm{~nm}$ into separate interpenetrated phases of $0.5-1.0 \mu \mathrm{m}$ [13]. Continuous growth of the phase at $t_{1}$ is a characteristic feature of the metastable liquation as a phase transition process. Significant specific volume of the nano-nonuniformities $(\approx 50$ vol. $\%)$ is an evidence of proximity of the treatment temperature $t_{1}$ to the temperature of the highest rate of opalescence growth.

Further thermal treatment of T3 glass (temperature $t_{2}=730^{\circ} \mathrm{C}$ ) leads to disappearance of the liquation picture and to formation of the fluctuation non-uniform structure of the glass with enlargement of separate nonuniformities due to gradual changes of composition of the new formations from droplet periphery to their center with sharp phase boundaries (Fig. 1c).

Evidence of their sharpness on the surface of spherical nonuniformitites are the shadows beyond the contours of droplets. Further structure ordering of spherical droplets due to high crystallization ability of experimental calcium silicophosphate glasses is observed on the boundaries of the droplets with size of $0.5-1.0 \mu \mathrm{m}$, evenly distributed in the glass matrix. Consequently, these droplets may act as crystallization centers.

At the thermal treatment of T3 glass (temperature $t_{3}=840^{\circ} \mathrm{C}$ ) the fluctuation nonuniform structure becomes smaller (Fig. 1d). 


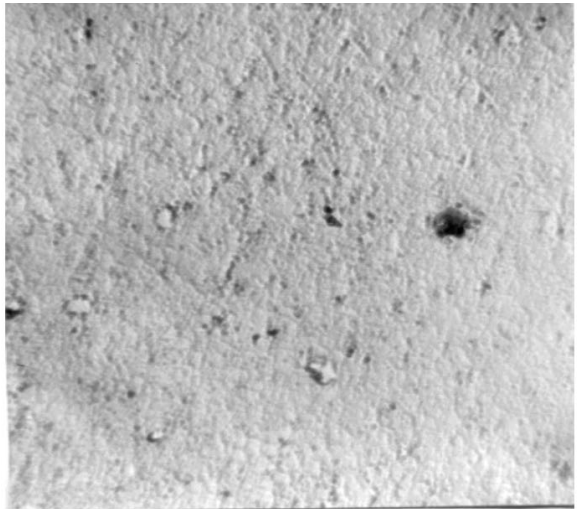

a)

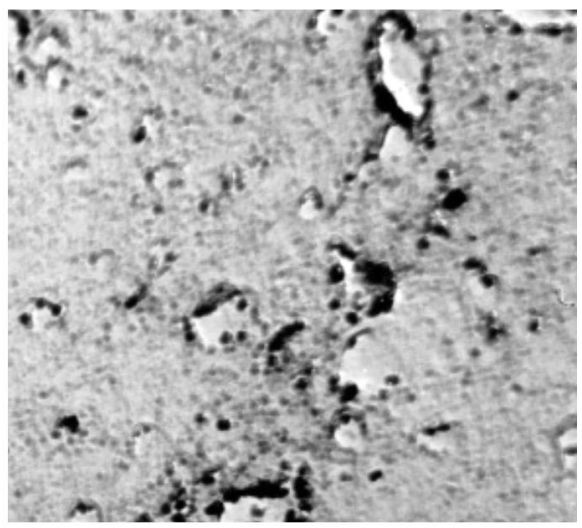

c)

Fig. 1. Structure of T3 glass material.

This is an evidence of fundamental difference between the fluctuation and liquation structures. It consists in the fact that the fluctuation nonuniformities at $t>t_{l}\left(t_{l}-\right.$ liquation temperature) cannot grow infinitely. One of the reasons of insignificant quantity of the phase nonuniformities after increasing temperature to $t_{2}$ apparently is the fact that at higher temperatures only relatively large crystals are formed. Therefore, liquid fluctuation areas may act as stable nuclei of the new phase. Another reason for decrease of quantity of the large nonuniformities with temperature increase is reduction of the amount of the phase that forms nuclei.

Therefore, partly ordered at temperature $t_{2}$ fluctuations of T3 glass, which have equilibrium compositions at temperature $t_{3}$ are the stable crystalline nuclei, and their stabilization takes place due to ordering of the structure. This manifests in changing of the droplets shape during the thermal treatment from convex to flat, which according to O.V.Mazurin [7] is an evidence of equilibrium in the system.

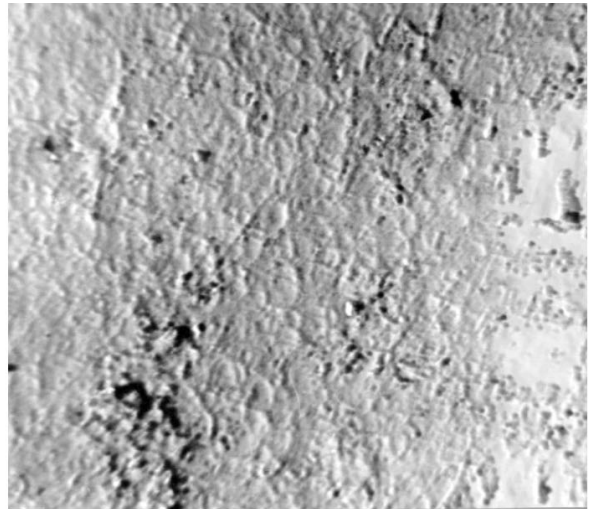

b)

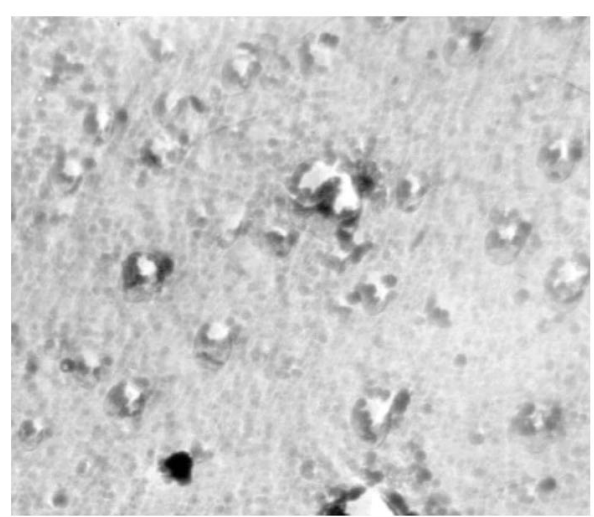

d)

Structure of original ZF-1 glass has nonuniform distribution pattern of the distinct dropwise particles with size of $0.5-$ $1 \mu \mathrm{m}$ and significantly differs from the structure of T3 glass (Fig. 1a, Fig. 2a).

Reduced viscosity of ZF-1 glass due to increased alkali content explains the size increase of its fluctuations in comparison with T3 glass. Compositional fluctuation run more easily in the low viscous $\mathrm{ZF}-1$ glass with $\eta_{600}=1.6 \cdot 10^{8} \mathrm{~Pa} \cdot \mathrm{s}$, than in the more viscous $\mathrm{T} 3$ glass with $\eta_{600}=$ $5.1 \cdot 10^{8} \mathrm{~Pa} \cdot \mathrm{s}$, in which each area of fluctuation doesn't have time to develop noticeably during favorable conditions for their occurrence and growth.

It is known [13] that the fluctuation structure has kinetic nature and hence it is able to develop significantly in the systems with low energetic barriers to structural and chemical transitions with low relaxation time, particularly in the systems with low viscosity.

Thus, in condition of the less viscous melt of ZF-1 glass near $t_{l}$ pre-transitional fluctuations have significantly larger size 


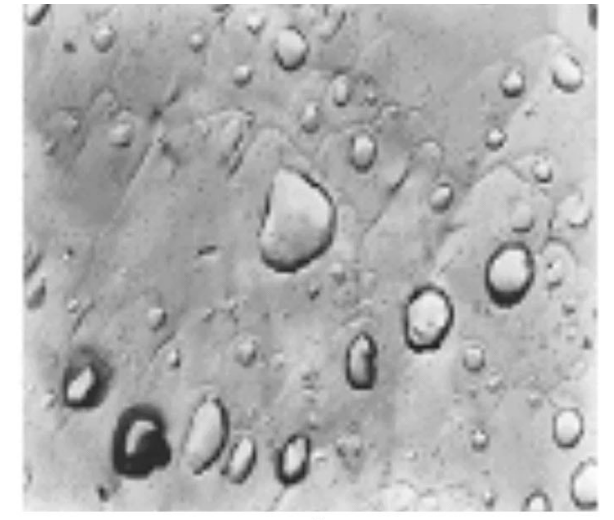

a)

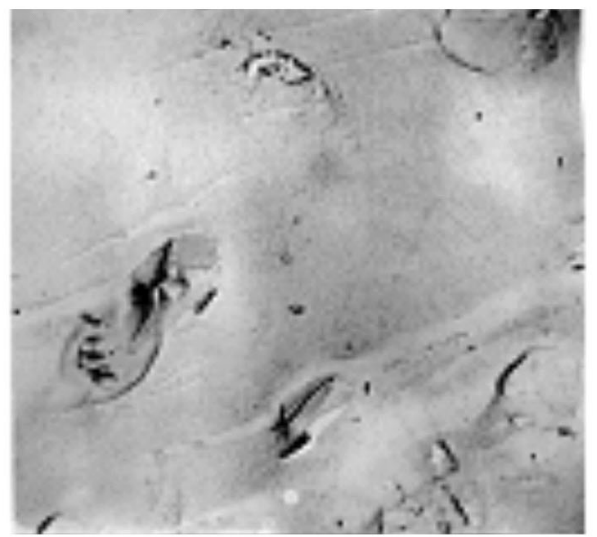

c)

Fig. 2. Structure of the ZF-1 Glass material.

than corresponding fluctuations in the more viscous T3 glass.

During thermal treatment of the original ZF-1 glass at temperature $t_{1}=600^{\circ} \mathrm{C}$ we observed accumulation of the spherical formations with size of $0.01-0.10 \mu \mathrm{m}$ (Fig. 2b) that appeared inside the similar formations with size of $0.5-1.0 \mu \mathrm{m}$ and were observed for this glass after cooling (Fig. 2a).

Occurrence of secondary segregation of the spherical formations in the experimental glass as a stage of heterogeneous formation of the crystalline centers is related to formation of the stabilized clusters - heterophase fluctuations that create self-organizing nanostructure. Increase in the rate of the phase separation process, manifested in formation of the nano- and micrononuniformities in the structure of $\mathrm{ZF}-1$ glass with consequent occurrence of nucleators and crystalline phase is explained by the presence of $\mathrm{ZnO}$ in it.

The structure of ZF-1 glass after the thermal treatment at $t_{2}=640^{\circ} \mathrm{C}$ has banded orientation (Fig. 2c).

It is represented by long blocks having $1 \mu \mathrm{m}$ in length, oriented towards the direc-

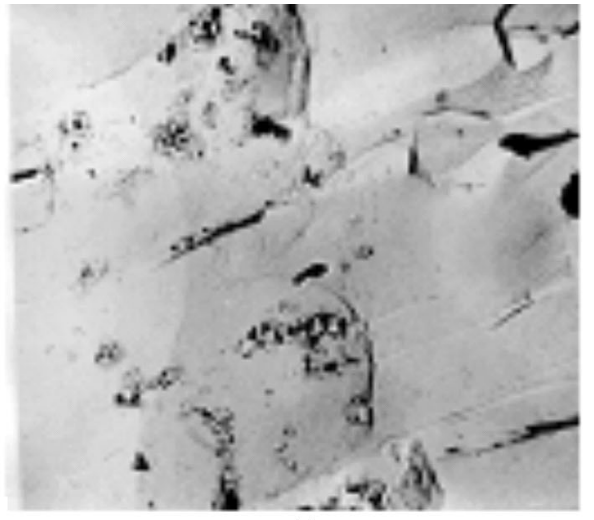

b)

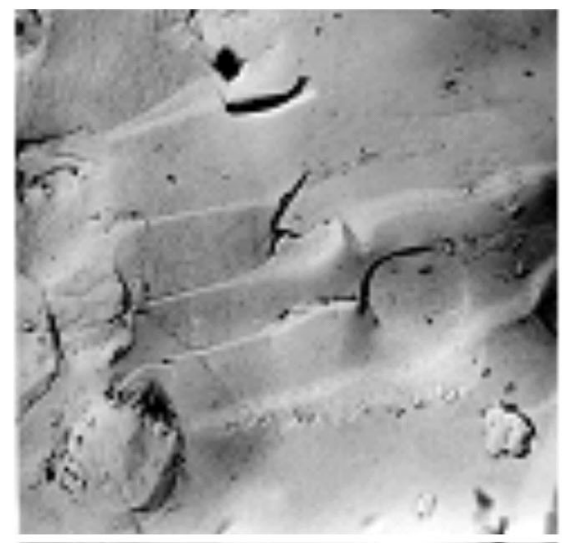

d)

tion of crystallization front having dropwise formation with the size of $\approx 0.01 \mu \mathrm{m}$ on them (Fig. 2b). Unsharpness of the block boundaries is explained by presence of the thin glass phase layer on them. The spherical nonuniformitites with size of $2 \mu \mathrm{m}$ with the presence of accumulated $0.1 \mu \mathrm{m}$ droplets on their boundary was observed near blocks, which may be the evidence of HAP crystals nucleation by liquation mechanism.

During the treatment of this glass at temperature $t_{3}=740^{\circ} \mathrm{C}$ quantity of the new formations increases and size of the spherical nonuniformities reduces. This fact along with formation of more uniform structure indicates the intensified volume crystallization process in this glass (Fig. 2d). Needle-like habitus of the crystals in Fig. $2 d$ is the evidence of presence of not only HAP, but also A-type CAP, which will provide increased bioactivity of the glass material.

It was established that thermal treatment of T3 and ZF-1 glasses at temperatures of $t_{4}=930^{\circ} \mathrm{C}$ and $880^{\circ} \mathrm{C}$ respectively leads to the volume fine crystallization in them with formation of HAP and CHAP crystals in the different quantities and with the different 
sizes. Presence of the liquation structure at temperature $t_{1}$ and fluctuation at temperature $t_{2}$ on the initial stages of the nucleation for T3 glass led to formation of HAP crystals with the size of $1-3 \mu \mathrm{m}$ in it in the quantities of $33 \%$ in it at the final crystallization temperature $t_{4}$. Process of innerdroplet liquation with the following ordering of the structure during thermal treatment of $\mathrm{ZF}-1$ glass and at the temperature $t_{4}=880^{\circ} \mathrm{C}$ in conditions of low-viscosity melt resulted in the increase of quantity of CHAP crystals to $55 \%$ and decrease of their size to $1 \mu \mathrm{m}$.

Provision of the glass-ceramic structure during the thermal treatment of ZF-1 and T3 glasses as well as presence of small crystals with the size of about $1 \mu \mathrm{m}$ in their structure will promote the increase of their hardness, which allows their use as polyfunctional bioactive materials on loaded bone areas.

Composition T3 with treatment temperature below $930^{\circ} \mathrm{C}$ is prospective as initial glass for obtaining the bioactive glass-ceramic coatings on titanium, considering TCLE values of titanium and its alloys $(\alpha=$ $\left.(100-120) \cdot 10^{7} l /{ }^{\circ} \mathrm{C}\right)$ as well as temperature range of formation of the brittle gas-saturated layer on them.

\section{Conclusions}

Mechanism of nucleation in experimental calcium phosphate glasses (glass materials) has been found. It consists in differentiation of the structure by the liquation mechanism with formation of the spherical nonuniformities inside microdroplets with the ollowing ordering of their structure.

Considering features of this mechanism it has been established that formation of the dropwise nano- and micro-nonuniformities in calcium silicophosphate glasses significantly influences separation of glass in precrystallization period and promotes intensive nucleation with following fine crystallization of carbonate hydroxyapatite after the thermal treatment, which is necessary for obtaining bioactive glass-ceramic materials and coatings with the high strength properties.

Principles of the structure formation of glass-ceramic materials and coatings as well as phase formation in them, which provide high functional and performance characteristics under heavy load conditions have been established.

\section{References}

1. B.I.Beletskii, N.V.Sventskaya, Glass and $\mathrm{Ce}^{-}$ ramics, 3, 26 (2009).

2. A.P.Shpak, P.Cheremskoy, Y.A.Kunitsky, Cluster and Nanostructured Materials. Vol. 3: Porosity as a Special Condition of the Self-organized Patterns in Solid Nanomaterials, Academedia, Kiev (2005) [in Russian].

3. P.D.Sarkisov, Directional Crystallization of Glass the Basis of Making a Multi-functional Ceramic Materials, RHTU im. Mendeleeva, Moscow (1997) [in Russian].

4. I.W.Donald, M.E.Brenchley, R.S.Greedharee, in: Proc. of XVIII Int. Congr. Glass, San Francisko (1998), p. AB 172.

5. A.Dogan, A.Genser, C.Peksen, in: Proc. of 20th Intern. Enameller Congr., Istambul-Turkey (2005), p.239.

6. I.P.Suzdalev, Physics and Chemistry of Clusters, Structures and Materials, Komkniga, Moscow (2006) [in Russian].

7. B.G.Varshal, Two-phase Glass: Structure, Properties, Applications, Nauka, Leningrad (1991) [in Russian].

8. L.A.Balskaya, L.A.Grechanik, N.M.Baysfeld, in: Proc. of the First All-union Symposium, Liquation Phenomena in Glasses, Leningrad, Russia (1969), p.88.

9. A.N.Lazarev, Vibrational Spectra and Structure of Silicates, Nauka, Leningrad (1968) [in Russian].

10. U.Y.Sedmale, in: Proc. Intern. Sci. Techn. Conf., Riga, Latvia (1990), p.4.

11. O.V.Savvova, O.V.Babich, G.N.Shadrina, in: Proc. of Ukrainian Res. Institute of Refractories behalf A.S.Berezhnoy, 112, 282 (2012).

12. O.V.Savvova, L.L.Bragina, O.V.Babich, Questions of Chem. and Chem. Technology, 5, 146 (2011).

13. N.A.Toropov, E.A.Popa-kosice, Structural Transformations in Glasses at Elevated Temperatures, Nauka, Moscow (1965) [in Russian]. 